\title{
Makna Perilaku Sosial Remaja Penikmat Kopi Lelet di Kota Rembang
}

\author{
Mario Fahmi Syahrial \\ Program Studi Pendidikan Ekonomi, Fakultas Keguruan dan IImu Pendidikan, Universitas \\ PGRI Ronggolawe Tuban \\ mariofahmi@unirow.ac.id
}

\begin{abstract}
ABSTRAK
Kebiasaan dan tradisi ngopi dalam perkembangannya juga diikuti oleh remaja di kota Rembang. Semula kebiasaan ngopi didominasi oleh orang dewasa dan orang tua, tapi kini dalam perkembangannya remaja yang sebagian besar pelajar mulai terpengaruh dan mengikuti kebiasaan ngopi. Budaya ngopi pada masyarakat Rembang telah berkembang dan melahirkan sub-kultur penikmat kopi lelet sebagian besar masih remaja. Penelitian ini menggunakan pendekatan kualitatif dan subjek penelitian adalah penikmat kopi di kotaRembang yang minum kopi lelet di warung kopi. Fokus penelitian adalah terhadap perilaku sosial remaja penikmat kopi lelet di Rembang. Tujuan penikmat kopi lelet berkumpul bersama selain bertujuan untuk menikmati secangkir kopi lelet juga memiliki tujuan untuk menjalin komunikasi, bertukar informasi dan menjalin keakraban antara sesama penikmat dan penikmat kopi. Perilaku sosial lain yang nampak dari penikmat kopi lelet adalah dari perilaku konsumsi, yang mana mempunyai selera kopi yang sama. Perilaku konsumsi yang dilakukan adalah minum kopi dan merokok. Aktifitas merokok, minum kopi (ngopi), dan melukis rokok dengan ampas kopi (nglelet rokok) pada saat nongkrong dan berkumpul bersama di warung kopi merupakan suatu hal yang wajib dilakukan, karena kopi dan rokok mampu mempererat dan mengakrabkan sesama penikmat kopi lelet. Minum kopi dan merokok di warung kopi sudah menjadi gaya hidup remaja di kota Rembang. Hal ini dikarena ada usaha dan keinginan untuk selalu memenuhi kebutuhan minum kopi dan merokok di warung kopi. Gaya hidup yang ditunjukan oleh remaja penikmat kopi lelet yang dapat diartikan sebagai ukuran harga diri dan munculnya perubahan perilaku menuju masyarakat konsumsi.
\end{abstract}

Kata Kunci: penikmat kopi, perilaku sosial, gaya hidup

\section{PENDAHULUAN}

Konsumsi masyarakat sekarang ini

tidak hanya untuk memenuhi nilai secara fungsional melainkan untuk memenuhi nilai simbolik. Baudrillard berpendapat, di dalam masyarakat konsumen yang berada di bawah bayang-bayang kapitalisme global produksi komoditi sama artinya dengan produksi "tontonan". Artinya, tujuan masyarakat mengkonsumsi suatu barang 
untuk menunjukkan suatu identitas. Mengkonsumsi komoditi sama dengan mengkonsumsi gaya hidup, mengkonsumsi identitas, ataupun status sosial, maka sebuah komoditi dibeli hanya untuk mempertontonkan identitas di depan orang lain (Kushendrawati, 2011).

Barang-barang yang semula sebatas kebutuhan sekunder dapat menjadi primer. Perubahan konsumsi masyarakat disini dalam arti konsumsi masyarakat bukan hanya sekedar memenuhi kebutuhan, akan tetapi juga pemenuhan kebutuhan yang memperhitungkan gengsi atau prestise. Perilaku konsumtif ini telah menjadi bagian dari gaya hidup dalam kehidupan masyarakat sekarang ini.

Gaya hidup merupakan pola-pola tindakan yang membedakan antara orang satu dengan orang yang lain. Gaya hidup berarti pemburuan penampilan diri dimuka publik dan pemburuan citra diri dipentas komunikasi massa. Gaya hidup penampilan adalah segalanya, seperti yang telah diungkapkan Chaney (2011) bahwa penampakan luar menjadi salah satu situs yang penting bagi gaya hidup. Seiring dengan perkembangan teknologi, iklan sebagai salah satu media massa yang telah menjadi semacam saluran hasrat manusia dan sekaligus saluran wacana mengenai konsumsi dan gaya hidup. Terkait gaya hidup Coffe Shop, sebenarnya istilah Coffe Shop adalah istilah asing. Coffe Shop sama halnya dengan kedai kopi. Kedai kopi merupakan num kopi sekarang ini, bukan hanya sekedar tuntutan selera atau kebutuhan, perkembangan istilah dari warung kopi. Sekarang ini Coffe Shop sedang tren dikalangan remaja di kota-kota besar. Remaja dikota-kota besar cenderung lebih bersantai dan minum kopi di coffe shop atau kedai kopi. Mimelainkan bagi sebagian remaja perkotaan sudah menjadi bagian dari gaya hidup.

Remaja yang hidup di kota-kota besar seperti Semarang dapat menikmati kopi yang ada di mall atau pusat perbelanjaan seperti Starbucks, Excelso, Coffee Luwak, J'Co Donuts and Coffee, dll. Istilah Coffe Shop di kota-kota kecil atau di daerah cenderung tidak dipakai, karena pada umumnya di kota-kota atau di daerah sering mengunakan istilah warung kopi. Warung kopi adalah istilah yang lebih populer di kota Rembang. Rembang merupakan sebuah Kota kecil di Propinsi Jawa Tengah yang terletak di jalur pesisir pantai Utara Jawa bagian timur, yang berbatasan dengan wilayah Propinsi Jawa Timur. Rembang dari segi geografis merupakan daerah dataran rendah yang memiliki bentangan pantai sepanjang 65 
km. Sebagian besar masyarakat memanfaatkan potensi pantai dan laut sebagai nelayan.

Masyarakat Rembang memiliki berbagai macam kebiasaan atau tradisi. Kebiasaan atau tradisi yang dilakukan adalah ngopi. Ngopi secara kultural terkait erat dengan budaya agraris dan maritim masyarakat di wilayah Rembang. Ketika musim kemarau petani tak bisa menanam padi, saat angin musim baratan nelayan tak bisa melaut, sehingga memiliki banyak waktu luang. Waktu luang digunakan untuk ngopi, karena ngopi menjadi semacam pelarian. Munculnya kebiasaan ngopi juga dipicu dari kebiasaan orang dewasa dan orang tua yang berkumpul di warung kopi pada jam atau waktu istirahat. Ngelaut adalah istilah yang digunakan sehari-hari masyarakat untuk menunjukan waktu istirahat. Waktu istirahat biasanya dihabiskan orang dewasa dan orang tua di warung kopi untuk berkumpul teman-teman dan untuk menikmati kopi.

Kebiasaan dan tradisi ngopi dalam perkembangannya juga diikuti oleh remaja di kotaRembang. Semula kebiasaan ngopi didominasi oleh orang dewasa dan orang tua, tapi kini dalam perkembangannya remaja yang sebagian besar pelajar mulai terpengaruh dan mengikuti kebiasaan ngopi.
Remaja yang menikmati kopi di warung kopi berasal dari berbagai latar belakang yg berbeda. Umumnya remaja minum kopi di warung kopi adalah untuk berkumpul dengan teman sebaya (kelompok teman sepermainan) untuk menghabiskan waktu bersama dan menikmati kopi di warung kopi. Kebiasaan ini menjadi budaya. Budaya ngopi pada masyarakat Rembang telah berkembang dan melahirkan sub-kultur penikmat kopi lelet sebagian besar masih remaja.

Adanya penikmat kopi lelet dikalangan remaja di kota Rembang dapat memicu perilaku dan perubahan sosial di masyarakat. Berdasarkan latar belakang di atas, maka penulis ini akan meneliti tentang Makna Perilaku Sosial Remaja Penikmat Kopi Lelet di Kota Rembang.

\section{TINJAUAN PUSTAKA}

\section{Perilaku Sosial}

Perilaku sosial adalah suasana saling ketergantungan yang merupakan keharusan untuk menjamin keberadaan manusia. Sebagai bukti bahwa manusia dalam memnuhi kebutuhan hidup sebagai diri pribadi tidak dapat melakukannya sendiri melainkan memerlukan bantuan dari orang lain. Ada ikatan saling ketergantungan diantara satu orang dengan yang lainnya. Artinya bahwa 
kelangsungan hidup manusia berlangsung dalam suasana saling mendukung dalam kebersamaan. Untuk itu manusia dituntut mampu bekerja sama, saling menghormati, tidak menggangu hak orang lain, toleran dalam hidup bermasyarakat.

Perilaku sosial seseorang itu tampak dalam pola respons antar orang yang dinyatakan dengan hubungan timbal balik antar pribadi. Perilaku sosial juga identik dengan reaksi seseorang terhadap orang lain. Perilaku itu ditunjukkan dengan perasaan, tindakan, sikap keyakinan, kenangan, atau rasa hormat terhadap orang lain. Perilaku sosial seseorang merupakan sifat relatif untuk menanggapi orang lain dengan cara-cara yang berbeda-beda. Misalnya dalam melakukan kerja sama, ada orang yang melakukannya dengan tekun, sabar dan selalu mementingkan kepentingan bersama diatas kepentingan pribadinya. Sementara dipihak lain, ada orang yang bermalasmalasan, tidak sabaran dan hanya ingin mencari untung sendiri. Sesungguhnya yang menjadi dasar dari uraian di atas adalah bahwa pada hakikatnya manusia adalah makhluk sosial (Gerungan, 2009).

Sejak dilahirkan manusia membutuhkan pergaulan dengan orang lain untuk memuhi kebutuhan biologisnya. Pada perkembangan menuju kedewasaan, interaksi sosial diantara manusia dapat merealisasikan kehidupannya secara individual. Hal ini dikarenakan jika tidak ada timbal balik dari interaksi sosial maka manusia tidak dapat merealisasikan potensi-potensinya sebagai sosok individu yang utuh sebagai hasil interaksi sosial. Potensi-potensi itu pada awalnya dapat diketahui dari perilaku kesehariannya. Pada saat bersosialisasi maka yang ditunjukkannya adalah perilaku sosial. Pembentukan perilaku sosial seseorang dipengaruhi oleh berbagai faktor baik yang bersifat internal maupun yang bersifat eksternal. Pada aspek eksternal situasi sosial memegang pernana yang cukup penting. Situasi sosial diartikan sebagai tiap-tiap situasi di mana terdapat saling hubungan antara manusia yang satu dengan yang lain (Gerungan, 2009). Dengan kata lain setiap situasi yang menyebabkan terjadinya interaksi sosial dapatlah dikatakan sebagai situasi sosial. Contoh situasi sosial misalnya di lingkungan pasar, pada saat rapat, atau dalam lingkungan pembelajaran pendidikan jasmani

\section{Teori Makna}

Ada beberapa asumsi yang melatar belakangi dicetuskannya teori makna. Teori makna ini tidak terlepas dari tokoh Mead 
dan Blumer. Fokus Mead (Ritzer dan Godman, 2009) berasal dari gagasan pragmatisme, ia memusatkan perhatian pada tindakan dan interkasi manusia, bukan pada proses mental yang terisolasi. Pokok perhatian utamanya adalah bukannya bagaiamana orang secara mental menciptakan makna dan simbol, namun bagaimana mereka mempelajarinya selama interaksi pada umumnya dan khususnya selama sosialisasi. Orang mempelajari simbol sekaligus mempelajari makna dalam interaksi sosial. Kendati merespon tanda tanpa berpikir, orang merespon simbol melalui proses berfikir.

Blumer dalam (Susilo, 2008) mengungkapkan bahwa makna memiliki peran penting pada kehidupan sosial, sebab ia menjadi dasar interaksi sosial dan mengarahkan tindakan kita pada orang lain atau sesuatu hal. Konsekuensinya, ia juga akan membentuk sifat interaksi tersebut, akankah bersahabat, bertentangan atau berkompetensi. Makna akan menjadi sumber konflik atau pertentangan ketika satu makna dianggap biasa, sementara bagi kelompok lain justru dipandang sakral, bahkan sering kali ekstrim dimaknai sebagai representasi harga diri. Karena itu dalam masyarakat makna harus dipahami secara subjektif. Bahkan jika ingin menciptakan keteraturan, masing-masing pihak harus berempati atas masing-masing makna subjektif tersebut. Kalaulah tidak sepakat dengan makna pihak lain, tetapi tidak harus ditunjukkan dalam bentuk sikap atau tindakan yang justru melecehkan atau merendahkan pihak lain.

Blumer (Susilo, 2008) memberikan gagasanya mengenai tiga hal yaitu: arti penting makna pada tindakan sosial, sumber-sumber makna dan peran makna dalam penafsiran, berdasarkan tiga premis tersebut dapat dipecah dalam tiga penjelasan, yaitu: manusia bertindak atas sesuatu pada dasar makna yang dimiliki benda tersebut. Dari situlah dinyatakan bahwa kesadaran merupakan elemen kunci dari tindakan bermakna. Makna merupakan produk sosial, diciptakan karena belum ada sebelumnya, dan tidak bersifat begitu saja ada. Makna dari sesuatu untuk seseorang muncul dari orang lain bertindak pada pihak lain dengan memperhatikan sesuatu. Tindakan mereka berjalan mendefinisikan sesuatu bagi sesorang. Blumer mengatakan bahwa individu mengomunikasikan dan memperlakukan makna lewat sebuah proses "bertanya pada dirinya". Seseorang menceritakan kebingungan dan kecemasan sedang menafsirkan apa yang dianggap mengganggu dirinya, dan Blumer menyatakan bahwa ini merupakan proses membuat tanda pada seseorang. 
Beberapa asumsi kaitannya dengan teori makna akan dijelaskan yang telah muncul adalah; Pertama: Manusia bertindak terhadap orang lain berdasarkan makna yang diberikan orang lain pada mereka. Penjelasan: perilaku sebagai suatu rangkai pemikiran dan prilaku yang dilakukan secara sadar antara rangsangan dan respon yang berkaitan dengan rangsangan tersebut. Jadi dalam hal ini saling mempengaruhi satu sama lain, baik akibatnya akan positif maupun akan negatif. Kedua: Makna diciptakan dalam interaksi antar manusia Penjelasan: Mead menekankan dasar intersubjektif dari makna. Makna dapat ada, menurut mead, hanya ketika orang-orang memiliki interpretasi sama mengenai simbol yang mereka pertukarkan dalam interaksi. Blummer (2008) menjelaskan bahwa terdapat tiga cara untuk menjelaskan asal sebuah makna: (1) makna adalah sesuatu yang bersifat intrinsik dari suatu benda. Blummer mengatakan jadi, sebuah bangku jelas-jelas merupakan bangku di dalam dirinya. Maknanya memancar, dapat dikatakan demikian, dari benda tersebut dan sepertinya tidak ada proses yang terlibat dalam pembentukannya, yang penting adalah untuk mengenali makna yang sudah ada dalam benda tersebut; (2) Asal-usul makna melihat makna itu "dibawa kepada benda oleh seseorang bagi siapa benda itu bermakna". Posisi ini mendukung pemikiran yang terkenal bahwa makna terdapat didalam orang, bukan di dalam benda. Dalam sudut pandang ini, makna dijelaskan dengan mengisolasi elemen-elemen psikologis di dalam seseorang individu yang menghasilkan makna.

\section{Remaja}

Hurlock dalam (Judhita, 2011) menyatakan remaja berasal dari kata latin adolensence yang berarti tumbuh atau tumbuh menjadi dewasa. Istilah adolensence mempunyai arti yang lebih luas lagi yang mencakup kematangan mental, emosional sosial dan fisik. Remaja sebenarnya tidak mempunyai tempat yang jelas karena tidak termasuk golongan anak tetapi tidak juga golongan dewasa atau tua. Seperti yang dikemukakan oleh Calon dalam (Judhita, 2011) bahwa masa remaja menunjukkan dengan jelas sifat transisi atau peralihan karena remaja belum memperoleh status dewasa dan tidak lagi memiliki status anak. Dari definisi diatas dapat disimpulkan bahwa masa remaja adalah masa peralihan dari masa anak-anak ke masa dewasa, dimana pada masa tersebut terjadi proses pematangan baik itu pematangan fisik, maupun psikologis.

Persepsi umum tentang remaja ada yang berpendapat bahwa merupakan kelompok yang biasa saja, tiada yang 
berbeda dengan kelompok manusia yang lain. Ada yang berpendapat bahwa remaja adalah kelompok orang-orang yang sering menyusahkan orang-orang tua. Ada pula yang berpendapat bahwa remaja merupakan potensi manusia yang perlu dimanfaatkan. Akan tetapi manakala remaja dimintai persepsinya, mereka akan berpendapat lain. Mungkin mereka berbicara tentang ketakacuhan atau ketidakpedulian orang-orang dewasa terhadap kelompok mereka. Mungkin juga berpersepsi bahwa kelompoknya adalah kelompok-kelompok minoritas yang memiliki dunia sendiri yang sulit dijamah oleh orang tua. Ada juga yang berpersepsi bahwa kelompoknya adalah kelompok yang bertanggung jawab terhadap masa depan bangsa dan negara (Mighwar, 2006).

\section{Kajian Pustaka}

Kajian Pustaka adalah beberapa penelitian yang telah dilakukan yang mempunyai kesamaan tema, namun berbeda objek penelitian dan teori yang dijadikan acuan peneliti. Hasil penelitian yang relevan dengan penelitian ini adalah penelitian yang dilakukan oleh Ibrahim dengan "Makna" Dalam Komunikasi. Menunjukan bahwa sebagai makhluk sosial, setiap manusia memangn mempunyai kemampuan dasar berkomunikasi antar sesama. Akan tetapi setiap manusia akan senantiasa memiliki perbedaan kemampuan dalam berkomunikasi, terutama menyangkut bahasa sebagai pilihan simbol dalam menyampaikan pesan, dan makna pesan yang hendak dipertukarkan melalui simbolsimbol komunikasi. Hal ini menyebabkan tidak semua komunikasi yang dibangun memperoleh hasil yang sama efektif. Dalam banyak contoh, kita gagal membangun komunikasi dengan baik, sesuai harapan dan maksud yang diinginkan. Bahkan tidak jarang kita terjebak dalam perangkap perbedaan simbol atau lambang komunikasinya saja, substansi yang hendak dipertukarkan justru terlupakan. Substansi inilah sebenarnya yang disebut dengan makna (mean-meaning), yakni suatu pesan yang diperoleh dari proses interaksi, dan itulah sesungguhnya yang dicari sebagai "makna" dalam komunikasi.

Penelitian yang relevan selanjutnya adalah hasil penelitian dari Paulus Hadisuprapto dengan judul Studi Tentang Makna Penyimpangan Perilaku Di Kalangan Remaja menunjukan, kenakalan sebenarnya relatif subyektif di mata komunitas remaja. Mungkin saja orang lain menganggap perilaku tertentu sebagai kenakalan,itu mungkin tidak dirasakan dengan cara yang sama oleh anak muda lainnya. Untuk memahami makna perilaku menyimpang yang diambil oleh anak muda 
dan bagaimana itu dipahami oleh mereka, penulis telah melakukan penelitian yang meliputi sekelompok pemuda. Penulis menyimpulkan dengan ini bahwa perbedaan makna jelas dan orang muda cenderung mengikuti perilaku yang mereka anggap positif.

\section{METODE PENELITIAN}

\section{Dasar Penelitian}

Metode penelitian yang digunakan peneliti dalam penelitian tentang perilaku sosial penikmat kopi lelet adalah penelitian dengan menggunakan pendekatan kualitatif. Penggunaan pendekatan kualitatif ini, karena yang diteliti adalah perilaku individu dalam komunitas atau kelompok, yang bersifat lisan yang mencakup catatan, laporan, dan foto-foto.

\section{Lokasi dan Letak Penelitian}

Penelitian ini dilakukan di warung kopi yang ada di kota Rembang.

\section{Fokus Penelitian}

Fokus penelitian ini meliputi empat hal, yaitu: menganalisis makna perilaku sosial penikmat kopi lelet di Kota Rembang.

\section{Subjek Penelitian}

Subjek penelitian adalah subjek yang dituju untuk diteliti oleh peneliti. Subjek penelitian ini merupakan pusat perhatian atau sasaran peneliti. Subjek dalam penelitian ini adalah penikmat kopi lelet di warung kopi yang ada dikota Rembang. Teknik yang dipakai hampir sama seperti teknik sampling yaitu Snowball Sampling (sampel bola salju).

\section{Metode Pengumpulan Data}

\subsection{Metode Wawancara}

Wawancara yang dilakukan dalam penelitian ini adalah; untuk mengetahui makna perilaku sosial yang meliputi perilaku sosial dari penikmat kopi lelet di kota Rembang.

\subsection{Metode Observasi}

Observasi dalam penelitian ini, peneliti terjun langsung ke lapangan yaitu di warung kopi untuk melakukan pengamatan dan pencatatan data secara langsung dan partisipan untuk makna perilaku sosial dari penikmat kopi lelet di kotaRembang.

\section{Validitas Data}

Membandingkan data hasil pengamatan atau observasi dengan data hasil wawancara dari data hasil observasi diperoleh data mengenai jumlah pelanggan, cara berinteraksi, bahan obrolan, konsumsi yang dilakukan, durasi waktu, menu 
makanan yang dipesan dan lamanya nongkrong dengan menikmati kopi lelet

\section{Metode Analisis Data}

Metode analisis data yang
digunakan dalam penelitian ini
menggunakan metode analisis dari Miles, dimana tahap analisis Miles mencakup: pengumpulan data, reduksi data, penyajian data, verifikasi data atau penarikan kesimpulan. Proses analisis data inilah yang nanti akan penulis gunakan untuk menganalisis data yang diperoleh dari lapangan. Penjelasan proses analisis tersebut adalah sebagai berikut:

Pengumpulan data: peneliti mencatat semua data secara objektif dan apa adanya sesuai dengan hasil observasi dan wawancara di lapangan. Wawancara yang dilakukan peneliti untuk memperoleh informasi tentang perilaku penikmat kopi lelet, yang meliputi; lokasi dan tempat berkumpul, sejarah, tujuan, aktifitas, perilaku konsumsi, pola interaksi, serta dampak yang ditimbulkan.

Reduksi data: memilih hal-hal pokok yang sesuai dengan fokus peneliti. Reduksi data merupakan suatu bentuk analisis yang menggolongkan, mengarahkan, membuang yang tidak perlu dan mengorganisasikan data-data yang direduksi memberikan gambaran yang lebih tajam tentang hasil pengamatan dan mempermudah peneliti untuk mencari sewaktu-waktu. Data yang tidak dibutuhkan dalam penelitian tidak dimunculkan dalam pembahasan, agar lebih mengarah pada fokus penelitian dan tidak membahas hal-hal yang dianggap tidak sesuai dengan fokus penelitian.

Penyajian Data: sekumpulan informasi tersusun yang memberikan kemungkinan adanya penarikan kesimpulan dan pengambilan tindakan. Penyajian data dilakukan setelah melakukan reduksi data yang akan dipergunakan sebagai bahan laporan. Penyajian data meliputi; gambar, peta, dan tabel. Penyajian data ini penulis melakukan dengan cara mengumpulkan data mengenaipenikmat kopi lelet Rengganis, khususnya yang berkaitan dengan profil, perilaku konsumsi dan perilaku seksual dan dampak. Peneliti memperoleh data melalui hasil wawancara, observasi dan studi dokumentasi di lapangan. Peneliti kemudian menyajikan data dalam bentuk deskriptif naratif yang berisi tentang uraian seluruh masalah yang dikaji sesuai dengan fokus penelitian yaitu makna perilaku sosial.

Pengambilan kesimpulan atau verifikasi: suatu kegiatan yang berupa pengambilan intisari dan penyajian data 
yang merupakan hasil dari analisis yang dilakukan dalam penelitian atau kesimpulan awal yang sifatnya belum benar-benar matang. Pada tahap penarikan kesimpulan ini penulis menyimpulkan data yang sudah diperoleh melalui observasi, wawancara dan studi dokumentasi di lapangan. Peneliti menyimpulkan data tersebut yang tentunya nanti mengarah pada fokus penelitian ini, yaitu Makna perilaku sosial.

\section{HASIL DAN PEMBAHASAN}

Perilaku sosial remaja penikmat kopi lelet di kota Rembang nampak dari suasana keakraban antar sesama penikmat kopi. Ada ikatan saling ketergantungan diantara satu orang dengan yang lainnya. Perilaku sosial dengan hubungan timbal balik antar pribadi identik dengan reaksi seseorang terhadap orang lain. Perilaku itu ditunjukkan dengan perasaan, tindakan, sikap keyakinan, kenangan, atau rasa hormat terhadap orang lain. Perilaku sosial seseorang merupakan sifat relatif untuk menanggapi orang lain dengan caracara yang berbeda-beda.

Tujuan penikmat kopi lelet berkumpul bersama selain bertujuan untuk menikmati secangkir kopi lelet juga memiliki tujuan untuk menjalin komunikasi, bertukar informasi dan menjalin keakraban antara sesama penikmat dan penikmat kopi.
Persepsi tentang penikmat kopi ini adalah menjalin komunikasi, bertukar informasi, dan menjalin keakraban, merupakan penafsiran yang unik terhadap situasi dan bukannya pencatatan yang benar terhadap situasi. Proses kognitif di atas adalah proses kegiatan mental yang sadar seperti sikap, kepercayaan dan pengharapan yang semuanya merupakan faktor yang menentukan perilaku atau tindakan (Thoha, 2000).

Perilaku sosial lain yang nampak dari penikmat kopi lelet adalah dari perilaku konsumsi, yang mana mempunyai selera kopi yang sama. Perilaku konsumsi yang dilakukan adalah minum kopi dan merokok. Aktifitas merokok, minum kopi (ngopi), dan melukis rokok dengan ampas kopi (nglelet rokok) pada saat nongkrong dan berkumpul bersama di warung kopi merupakan suatu hal yang wajib dilakukan, karena kopi dan rokok mampu mempererat dan mengakrabkan sesama penikmat kopi lelet.

Minum kopi (ngopi), merokok, dan ngelelet rokok bagi penikmat kopi lelet di Rembang dapat dimaknai sebagai gaya hidup. menurut Blumer (Susilo, 2008) aktifitas minum kopi dan merokok dapat diartikan sebagai manusia bertindak atas sesuatu pada dasar makna yang dimiliki benda tersebut. Benda tersebut dinyatakan 
dalam kesadaran merupakan elemen kunci dari tindakan bermakna. Makna merupakan produk sosial, diciptakan karena belum ada sebelumnya, dan tidak bersifat begitu saja ada. Makna dari sesuatu untuk seseorang muncul dari orang lain bertindak pada pihak lain dengan memperhatikan sesuatu, aktifitas yang dilakukan oleh penikmat kopi lelet dapat dimaknai sebagai gaya hidup dan juga merupakan kebutuhan.

Perilaku sosial remaja penikmat kopi lelet dapat diartikan sebagai sebuah bahasa dan komunikasi, merokok, minum kopi (ngopi), dan melukis rokok dengan ampas kopi (ngelelet rokok) digunakan untuk menyampaikan pesan dan makna sosial, hal ini dapat melalui penyajian kopi, minum kopi, tempat minum kopi, dan warung kopi. Melihat selera sebagai sesuatu yang dikonstruksi secara sosial dapat dibedakan menjadi dua, antara lain 1) selera dilihat sebagai keharusan yaitu selera yang menutamakan fungsi konsumsi (kesenangan dan ekonomi); 2) selera kebebasan atau kemewahan yang mengutamakan tata cara atau gaya dalam mengonsumsi (penampilan, penyajian, dan cara mengonsumsi). Menurut Piliang selera dilihat sebagai penanda kunci perbedaan kelas. Perubahan dalam kelas-kelas social akan mengubah gaya dan selera dalam mengonsumsi sesuatu. Selain itu perubahan gaya dan selera juga dipengaruhi oleh peningkatan tempo kehidupan sebagai akibat dari percepatan yang terjadi dalam aktivitas ekonomi, sosial, dan teknologi. Perubahan inilah yang mendasari perubahan kearah masyarakat konsumer (Adlin, 2006).

\section{KESIMPULAN.}

Penikmat kopi lelet di Rembang menjadikan warung kopi sebagai tempat untuk nongkrong dan berkumpul. Aktifitas yang dilakukan mengobrol dengan merokok, minum kopi (Ngopi), dan melukis rokok dengan ampas kopi (ngelelet rokok) dimaknai sebagai bentuk keakraban dan kedekatan hubungan antar sesama penikmat kopi lelet. Minum kopi dan merokok di warung kopi sudah menjadi gaya hidup remaja di kota Rembang. Hal ini dikarena ada usaha dan keinginan untuk selalu memenuhi kebutuhan minum kopi dan merokok di warung kopi. Gaya hidup yang ditunjukan oleh remaja penikmat kopi lelet yang dapat diartikan sebagai ukuran harga diri dan perubahan perilaku menuju masyarakat konsumsi.

\section{DAFTAR PUSTAKA}

Adlin, Alfathri. 2006. Menggeledah Hasrat : Sebuah Pendekatan Multi Perspektif. Yogyakarta : Jalasutra.

Chaney, David. 2004. Lifestyles: Sebuah Pengantar Komprehensif. Yogyakarta : Jalansutra 
Gerungan. 2009. Psikologi Sosial. Bandung: PT Refika Aditama.

Hadisuprapto, Paulus. 2004. Studi Tentang Makna Penyimpangan Perilaku Di Kalangan Remaja. Jurnal Kriminologi Indonesia, 3 (3), 9 - 18

Judhita, Christiany. 2011. Hubungan Pengunaan Situs jejaring Sosial Facebook terhadap Perilaku Remaja di Kota Makassar. Balai Besar Pengkajian dan Pengembangan Komunikasi dan Informatika. 13(1). Hal: 1-23.

Kushendrawati, Selu Maragaretha. 2011. Hiperrealitas dan Ruang Publik: Sebuah Analisis Cultural Studies. Jakarta: Penaku.

Mighwar, Muhammad A. 2006. Psikologi Remaja: Petunjuk bagi Guru dan Orang Tua. Bandung: Pustaka Setia.

Ms.lbrahim. 2015. Makna Dalam Komunikasi. Alhikmah, 9(1), 18-29

Ritzer, George dan Goodman, Douglas J. 2009. Teori Sosiologi (dari teori sosiologi klasik sampai perkembangan mukhtahir teori sosial post modern). Yogyakarta: Kreasi Wacana.

Susilo, Racmad K. Dwi. 2008. 20 Tokoh Sosiologi Modern. Yogyakarta: Arruz Media.

Thoha, Miftah. 2010. Perilaku Organisasi. Jakarta: Raja Grafindo Persada. 